the Foundation's meeting were of high quality, but we need more of them and further opportunities to let them do their work.

Connoisseurs of MCP's remarks may read what they like into the following statement by a Commissioner of Police in the 1950s and discovered by some research workers on violence in the home. From the police point of view, with motive and perpetrator known, the crime may not be of great significance, but he might have put it more felicitously: 'In London there are about $\mathbf{2 0}$ murders a year, but not all of them are serious-some are just husbands murdering their wives'.

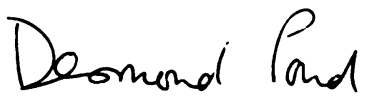

\title{
REGIONAL ADVISERS
}

After a process of consultation with the Divisions, the Academic Departments and Post-Graduate Deans, the Court of Electors has endorsed the following list of College Regional Advisers:

North East: Northern: Dr. D. L. F. Dunleavy; Yorkshire: Dr. Julian Roberts

North West: Mersey: Dr. M. D. Enoch; North Western: Prof. W. I. N. Kessel

Midlands: Trent: Prof. S. Brandon; West Midlands: Prof. Sir W. H. Trethowan

South Western: South Western: Prof. Gethin Morgan; Wessex: Dr. B. Barraclough

Chiltern and Thames Valley: Oxford: Dr. E. B. O. Smith; North West Thames: Dr. K. L. Granville-Grossman

East Anglian: East Anglia: Sir Martin Roth; North East Thames: Prof. D. A. Pond

Southern: South East Thames: Prof. R. Cawley; South West Thames: Dr. J. S. Stead

Welsh: Wales: Prof. K. Rawnsley

Scotland: North East: Dr. D. Le Poidevin; East: Dr. P. G. Aungle; South East: Dr. P. Kennedy; West: Dr. J. Clark

Ireland: Northern Ireland: Dr. W.A. G. MacCallum; Republic of Ireland: Dr. F. P. O'Donoghue

H.M. Forces: Navy: Dr. E. B.O. Smith; Army: Dr. Denis Leigh; R.A.F.: Prof. W. Linford Rees

\section{TRAINEES' SESSION}

A second session of trainees' papers on research topics is being organized as part of the programme for the Annual Meeting in July 1980.

Trainees and young psychiatrists (below the rank of Consultant) are invited to give a ten-minute paper on some investigation which they have or are in the process of undertaking.

Please let us have a title and an abstract (250 words maximum) by mid-April 1980 and contact Jane Boyce at the College address if you have any queries.

A. C. P. Sims on behalf of Programmes and Meetings Committee
The principal function of the Regional Advisers is to represent the College on Regional Committees in postgraduate medical education. The precise arrangements vary considerably from one Region to another. In many Regions the College Adviser is also the Chairman of the committee arranging local postgraduate training courses, and he may also act as adviser to those seeking a career in psychiatry. The College expects that the Adviser will work closely with the Academic Department of Psychiatry, and with its Divisions, in order to co-ordinate postgraduate training arrangements. Another, and equally important, function in England and $W$ ales is for the Adviser to comment on the job description for new and replacement consultant posts. The Adviser will be assisted by the Chairman or Secretary of Specialist Sections where the job is in a specialty other than his own.

These Regional Advisers are not to be confused with the College's Local Advisers on Distinction Awards. A description of the arrangements which the College has for making nominations for these awards was published in the Bulletin, March 1978.

Gerald C. Timbury Registrar

\section{CUTS IN THE NHS*}

The Executive Committee of the Social and Community Psychiatry Section wish to collect and collate information regarding recent and proposed cuts in Mental Health Services, including NHS and local authority funded services. I would be grateful if members would let me know of any cuts in their local areas.

A. C. Brown

Secretary, Social and Community Psychiatry Section

-The Registrar has also written to all College Divisions and Regional Advisers asking for the same information. 